\title{
Population dynamics of Salmincola salmoneus on Atlantic salmon in a northern Norwegian river
}

\author{
S. Kusterle ${ }^{*}$, R. Kristoffersen, A. H. Rikardsen \\ Faculty of Biosciences, Fisheries and Economics, Department of Arctic and Marine Biology, University of Tromsø, \\ 9037 Tromsø, Norway
}

\begin{abstract}
Atlantic salmon Salmo salar are often heavily infected by the gill maggot Salmincola salmoneus, but little information exists on the population dynamics of this parasite. Through a combination of in vivo field examination and laboratory analysis of gills from the Alta River S. salar population in northern Norway, we describe the population dynamics of the parasite and suggest a model for the host-parasite interactions. S. salar did not become infected with $S$. salmoneus until they returned to the river as first-time spawners. The infection increased rapidly until autumn, and just after spawning $96 \%$ of the spent fish (kelts) were infected with a mean intensity of 53 parasites per fish. In May, the prevalence of $S$. salmoneus on the descending kelts had increased to $100 \%$, but the intensity exhibited little change. A small proportion of the adult $S$. salar population returned as immature to the river during autumn and had lower parasite intensities than the kelts the following spring. When the fish that had spawned previously (repeat spawners) returned from their second (or more) sea migration, they had an average infection rate of $36 \mathrm{~S}$. salmoneus individuals per fish. The kelts seemed to be the main habitat for the parasite during winter and spring, and they stay long enough in the river to pass the infection to maiden $S$. salar that enter the river early in summer. These fish then became a source of infection for the maiden fish entering the river later. However, in years that have a possible mismatch between the opposite migration of kelts and maiden $S$. salar, the immature fall-running and returning repeat spawners will be crucial for maintaining the parasite population. We hypothesize that heavily infected $S$. salar may suffer reduced growth and survival at sea, potentially reducing the abundance of repeat spawners.
\end{abstract}

KEY WORDS: Parasitism · Anadromy $\cdot$ Migration $\cdot$ Salmo salar $\cdot$ Gill maggot $\cdot$ Copepod

\section{INTRODUCTION}

The Atlantic salmon Salmo salar is infected by many different parasites in both freshwater and saltwater habitats, and some parasites have a detrimental effect upon their host population (Bristow \& Berland 1991, Bristow 1993, Bristow et. al 1996). In Norway, for instance, the freshwater monogenean Gyrodactylus salaris and the marine copepod Lepeophtheirus salmonis are known to be partially responsible for the decline in the numbers of $S$. salar during the last few decades (Johnsen \& Jensen
1991, Heuch et al. 2005, Finstad et al. 2011, Harris et al. 2011). Another parasite species that has previously been recorded on Norwegian $S$. salar with high abundances is the salmon gill maggot Salmincola salmoneus (Smith 1983, Berland 1993, A. H. Rikardsen pers. obs.), but to our knowledge no studies on the population dynamics of this parasite have so far been published. Unlike most other external parasites that utilize $S$. salar as a host either in fresh water or salt water (Harris et al. 2011), S. salmoneus is one of the few external parasites (Bristow et al. 1996) that is perfectly adapted to remain attached to 
its host in both fresh and salt water. Despite this, it has generally attracted so little attention that it is not even mentioned in the parasite chapter (Harris et al. 2011) of a recent book on S. salar ecology. However, the parasite was first described in 1766, and the first life history description of S. salmoneus was provided by Friend (1941), who based his work on S. salar caught in Scotland, UK. The copepod is not confined to the European S. salar stock, but is also found on $S$. salar from the North American east coast, where research by Kabata \& Cousens (1973) led to some general corrections concerning the life stages. The parasite, like its host, reproduces in fresh water. The nauplius stage is passed in the egg, and a few minutes after hatching, the infective copepodid larva, lying on the river bed, actively starts to search for potential hosts by reacting to shadows and movements in the water. After finding a host, the larvae pass through 4 chalimus stages before females permanently attach themselves to the host gills and males drop off the host after mating (Friend 1941, Kabata 1981).

The Salmo salar population in Alta River in northern Norway has been studied extensively over several years and has for centuries been one of the most popular S. salar angling rivers in the world owing to the presence of large individual salmon and high catch efficiency (e.g. Næesje 1998, Rikardsen et al. 2004, Ugedal et al. 2007, 2008, 2009, Davidsen et al. 2009, Halttunen et al. 2009). Based on this, the Alta River was chosen as our study site in order to investigate the population dynamics of Salmincola salmoneus in a northern $S$. salar population. Here, the juvenile S. salar, known as parr, live on average for 3 to $4 \mathrm{yr}$ in the river before they undergo the process of smoltification and migrate to the sea as smolts in June and July (Rikardsen et al. 2004). After 1 to 4 winters in the sea, the adult fish return during June to August and spawn in October. After spawning (kelts), most of the surviving fish stay in the river during winter and leave in May and June during the spring spate. Some of them may later return to spawn again as repeat spawners (Halttunen et al. 2009). A curiosity within the river is the occurrence of immature fall-run $S$. salar. These fish ascend the river in late fall but do not participate in the spawning the same year, and seem to stay in the river for 1 yr before they spawn (A. H. Rikardsen et al. unpubl. data). The different S. salar life history stages represent different host opportunities for $S$. salmoneus. Some may be important for the parasite, while others might not be used at all (Friend 1941).
In Scotland, Friend (1941) registered the first infections of Salmincola salmoneus during the Salmo salar life cycle on maiden $S$. salar some time after the fish had returned to the river after their feeding migration at sea. The infection intensity on these fish increased during summer and until December to February. During spring (March to May), the infection intensity decreased. Copepodid larvae were recorded on fish in fall and during January, but not from February to May. Spent fish in spring were not found to be susceptible to new infections (Friend 1941). The maximum time from infection to reproduction for a $S$. salmoneus individual was calculated by Friend (1941) to be $5 \mathrm{mo}$, but in reality is probably shorter, depending on the water temperature (McGladdery \& Johnston 1988). Friend (1941) also suggested that only adult S. salar are suitable as hosts for the parasite, and that only adult $S$. salmoneus are able to survive seawater. However, some infected $S$. salar smolts have been reported from North America (Sandeman \& Pippy 1967, Kabata 1969), and $S$. salmoneus on maiden $S$. salar at sea have even been suggested as a biological tag for $S$. salar with a North American origin (Pippy 1969).

The aim of the present study was to examine how the Salmincola salmoneus population in a northern Norwegian river interacts with the different life stages of $S$. salar, and to evaluate the importance of these stages for the maintenance of the parasite population. The results are compared with existing literature on $S$. salmoneus and the life history of S. salar from more southern European populations. Based on the above we had the following expectations: (1) maiden $S$. salar at sea are not infected with $S$. salmoneus, (2) overwintering fish in the river and previously spawned fish in the sea carry copepods, and (3) adult fish in the river during spring are likely to be a source of infection for uninfected, maiden $S$. salar that enter the river during summer. In addition, we try to evaluate the possible influence of the copepod upon the $S$. salar population.

\section{MATERIALS AND METHODS}

The field work for this study was performed in the lower parts of the Alta River $\left(70^{\circ} \mathrm{N}, 23^{\circ} \mathrm{E}\right)$ and in the Alta fjord. The main river is approximately $240 \mathrm{~km}$ long and has a drainage area of approximately $7400 \mathrm{~km}^{2}$. The maximum water temperature is usually between 14 and $16^{\circ} \mathrm{C}$ in August (Ugedal et al. 2009). The river drains into the Alta fjord, which is 
$30 \mathrm{~km}$ long, $15 \mathrm{~km}$ at its widest and $488 \mathrm{~m}$ at its deepest (Rikardsen et al. 2004). The fjord opening is to the north into the northeastern Atlantic Ocean through 3 straits.

Sample fish were caught during different seasons throughout the year to obtain data on new infections, parasite egg production and life stages of Salmincola salmoneus attached to them. Salmo salar of different life stages were either examined alive at the site of capture or sampled and had their gill apparatus analyzed thoroughly in the laboratory.

\section{Sample material}

The material for this study was collected during 2006 to 2009 (Table 1). However, during several time periods, the data largely consisted of infection scores from living fish (see 'Sampling in the river'). Since this study focuses on the Salmincola salmoneus population's interactions with the wild Salmo salar population in the river, fish that obviously were farmed were excluded from the data analysis as far as they were recognized either visually (river and sea) or by scale analysis (sea) (Lund et al. 1989).

\section{Smolts}

A total of 45 Salmo salar smolts (11 to $15 \mathrm{~cm}$, average $=13 \mathrm{~cm}$ ) were caught from 24 to 28 June 2007 in a smolt trap placed approximately $9 \mathrm{~km}$ upstream from the estuary (Davidsen et al. 2009) (Table 1). The smolts were euthanized by a lethal treatment with the anesthetic 2-phenoxyethanol and frozen whole in plastic bags for transportation and later examination. The gills from the smolts were analyzed in the laboratory in the same way as adult fish (see 'Laboratory analysis').

\section{Adult fish}

Sampling in the fjord

A random sample of fish was obtained from returning Salmo salar caught in commercial fisheries with bag and bend nets in the fjord without causing damage to the gills. The fish were caught in different locations in the fjord at varying distances ( 3 to $20 \mathrm{~km}$ ) from the river mouth. The fishers measured fork length and weight, took scale samples, listed gender and froze the gills in plastic bags for laboratory analysis. A total of 133 gill samples from S. salar caught at sea were analyzed for the presence of Salmincola salmoneus (Table 1). The scale samples taken from all $S$. salar caught at sea were analyzed at the Norwegian Institute for Nature Research (NINA), Trondheim, in accordance with Dahl (1910) to determine whether the individual fish had spawned earlier.

\section{Sampling in the river}

During the fishing season in summer 2008, 29 gill samples as well as data for length, weight, sex and existing infections with salmon lice Lepeophtheirus salmonis were collected from salmon caught by rod anglers in the river. L. salmonis is a marine parasitic copepod that will fall off after some time (up to $3 \mathrm{wk}$ ) in fresh water (Hahnenkamp \& Fyhn 1985, Finstad et al. 1995) and so its presence indicates the recent arrival of a fish to the river. The absence of L. salmonis was seen as an indication of a longer stay in the river. The weight of an average fish of this group was about half the weight of an average Salmo salar caught at sea (Table 1), possibly due to size selection of fish by the anglers. Large female fish are released since they are regarded as the ones that maintain the $S$. salar population, while small male salmon were often killed (S. Kusterle pers. obs.).

Table 1. Salmo salar. Overview of sampling periods, size and sex ratio (\% female) of sampled fish. Number of fish (n) are given both for the total number of fish captured and for fish examined in the laboratory (laboratory number in brackets). -: no data

\begin{tabular}{|c|c|c|c|c|c|c|c|c|c|}
\hline \multirow{2}{*}{ Life stage } & \multirow{2}{*}{ Time of capture } & \multirow[t]{2}{*}{$\mathrm{n}$} & \multicolumn{3}{|c|}{ — Length $(\mathrm{cm})$} & \multicolumn{3}{|c|}{ — Weight $(\mathrm{kg})$} & \multirow{2}{*}{$\begin{array}{c}\text { Sex ratio } \\
\text { (\% female) }\end{array}$} \\
\hline & & & Mean & Min. & Max. & Mean & Min. & Max. & \\
\hline Smolt & June 2007 & $45(45)$ & 12.8 & 11 & 15 & - & - & - & - \\
\hline Returning adult/sea & June-August 2008 & 133 (133) & 95.5 & 54 & 124 & 10.4 & 1.9 & 20.2 & 65 \\
\hline Returning adult/river & June-August 2008 & 29 (29) & 74.1 & 44 & 119 & 5.3 & 0.7 & 17.5 & 31 \\
\hline Fall kelts & October 2006, 2008 & $4(4), 55(23)$ & 90.3 & 48 & 111.5 & 7 & 1.2 & 13 & 79 \\
\hline Spring kelts & $\begin{array}{c}\text { May-June } 2007 \\
2008,2009\end{array}$ & $\begin{array}{c}15(15), \\
198(19), 99\end{array}$ & 86.4 & 45 & 116 & 5.3 & 0.9 & 11.5 & 72 \\
\hline Fall immature & October 2007, 2008 & $9(1), 3(1)$ & 89.3 & 50.5 & 103.5 & 9.5 & 1.2 & 14.3 & - \\
\hline Spring immature & May 2008, 2009, 2010 & $12(4), 1,7$ & 78.5 & 49.5 & 102.5 & 6 & 0.9 & 11.8 & - \\
\hline
\end{tabular}


In fall, when most Salmo salar from the summer run of the same year had spawned, samples were caught by rod and spoon lure with barbless hooks, and the same method was used to obtain samples in spring. Most of these fish were released as part of a tagging project. However, prior to tagging, the fish were kept in a cage in the river for up to $2 \mathrm{~h}$ before being anesthetized nonlethally with 2-phenoxyethanol. While the fish were in the tub with the anesthetic solution waiting for surgery, scores of the Salmincola salmoneus infection intensities were made by lifting the operculum on both sides and counting the copepods seen on the gills. These field scores were divided into the following groups (number of parasites seen on an individual fish in vivo are included in brackets): 1 (1-3), 2 (4-6), 3 (7-10), 4 (11-17), 5 (18-23), $6(24-30), 7(31-40), 8(41-50), 9(51-60)$ and 10 (>60). The fish were then tagged, and fork length, weight, gender, sexual maturity and place and date of capture were recorded. Some $S$. salar were not tagged and released, but instead euthanized by an overdose of anesthetic, and their gill apparatus was immediately removed after recording the infection intensity score using the same scoring method as on the released fish. The gill samples were put in separate plastic bags and frozen until the numbers of parasites were counted in the laboratory (see next subsection). This method was followed to provide data for a comparison of the infection score in the field with the exact laboratory count of parasites. Thus, the accuracy of the field scores could be evaluated and data from released fish compared with fish examined in the lab.

In the fall of the years 2006, 2007 and 2008, a total of 61 Salmo salar were caught during field work. Of these, 29 were taken to the laboratory for a thorough analysis of the gills. The remaining fish were tagged and released in the river. Since the field work was done towards the end of the spawning season, most sampled $S$. salar that had entered the river during the summer had spawned. Two immature fall-run $S$. salar were caught and are included in the 29 samples that were taken to the laboratory (Table 1).

A total of 225 Salmo salar were caught during field work in spring 2007 and 2008. The gills of 34 spring kelts and 4 immature fall-run $S$. salar were taken to the laboratory for an accurate parasite count. The other kelts and 8 immature fall-run S. salar were tagged and released after a score of their parasite infection intensity had been obtained (Table 1). In addition, scores from 99 kelts caught during field work in spring 2009 in the river were obtained and were used to supply the laboratory data when necessary.

\section{Laboratory analysis}

In the laboratory, the gills were thawed before examination and carefully flushed with physiological saline to remove coagulated blood and other loose tissue. The copepods' attachment to the gills was so strong that the current from a wash bottle was not able to dislodge them unless they had been damaged from earlier improper treatment, such as drying or incautious handling of the sample (S. Kusterle pers. obs.). The 4 gill arches of each side of the fish were cut loose and flushed with physiological saline from both sides in a tray. Some copepods fell off during the flushing, but were easy to spot in the tray. The number of parasites for each gill arch was determined from both sides by using a magnifier and spreading the gill filaments apart with tweezers and needles, while the gill arch was placed in a petri dish with physiological saline. All Salmincola salmoneus were cut loose from the gill arch with a part of the gill filament they were attached to and placed in $96 \%$ ethanol for preservation and later analysis of their development stage.

\section{Salmincola salmoneus analysis}

The copepods from each fish were designated to one of the following 4 groups according to Friend (1941): (1) before the last ecdysis (individuals that had not attached themselves with a bulla), (2) immature (trunk thinner than the head), (3) mature (trunk wider than the head) and (4) mature with eggs (Fig. 1). All copepods with eggs, irrespective of the number of eggs per egg sac, were designated to the group 'mature with eggs'. Individuals with ruptured, empty egg sacs were counted as 'mature'. Damaged copepods, where only a part of the parasite was still attached to the gill filament, were only included in the total infection numbers. The separation into different groups was mainly done under a stereomicroscope.

\section{Statistics and data analysis}

Chi-square tests were used to compare the prevalence of infection between different groups of fish, while Student's $t$-tests were used to compare infection intensities. The logarithm of infection intensities was used to perform $t$-tests in order to prevent high variances based on aggregated distribution of infection. A linear regression was used to investigate the 

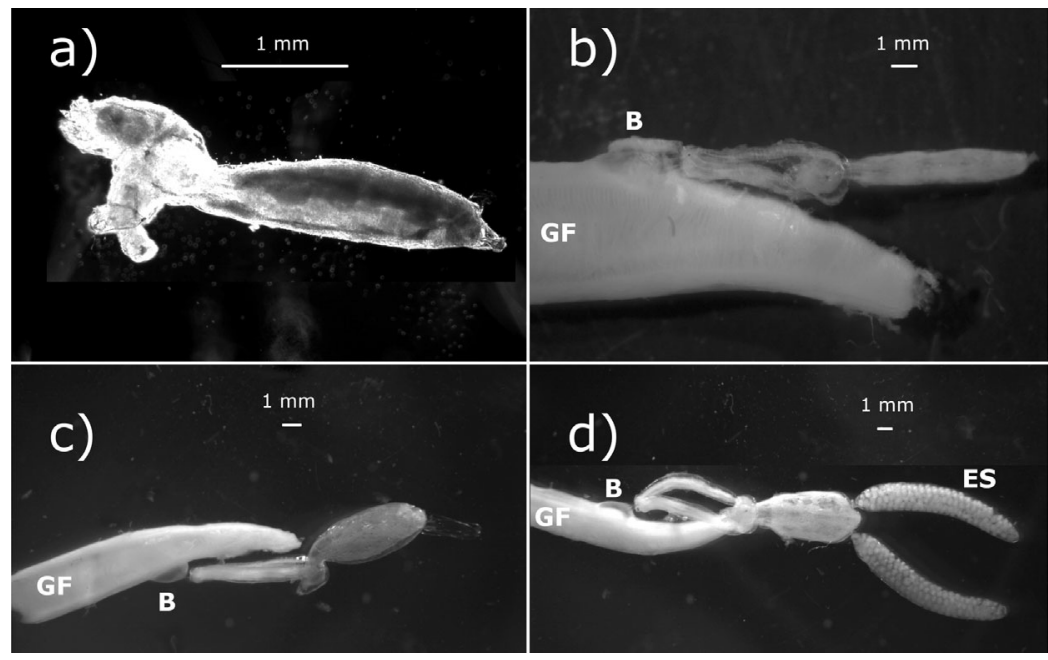
(prior to final infestation); (b) immature female (permanently attached to the gill filament); (c) mature female; (d) mature female with eggs in the egg sacs B: bulla; GF: gill filament; ES: egg sacs (photo: S. Kusterle)
Fig. 1. Salmincola salmoneus. Different life stages of the parasite: (a) chalimus

$\times x^{1.1444}\left(\mathrm{R}^{2}=0.79\right)$ was achieved. Linear and exponential trend lines were also fitted to the data, but both gave lower $\mathrm{R}^{2}$ values and were hence rejected. The formula was then used to calculate the approximate real infection for each released fish: $x=$ parasite intensity according to the score in the field, $y=$ rectified parasite intensity. These calculated infection data were then used in the subsequent work.

The terms prevalence, intensity and abundance are used as suggested by Bush et al. (1997), and the condition factor $(K)$ was calculated for each fish from the fish wet mass in grams $(W)$ and the fish length in centimeters $(L)$ from the formula: $K=(W \times 100) / L^{3}$ (Weatherley 1972).

\section{RESULTS}

relationship between host condition and infection intensity.

Returning female and male fish caught in the river in fall and spring, and returning spawners caught at sea that had been examined in the laboratory, were compared to detect any gender-specific infection. The infection prevalence between female $(96.7 \%$, $\mathrm{n}=60$, average length $=97 \mathrm{~cm})$ and male $(92 \%, \mathrm{n}=$ 25 , average length $=72 \mathrm{~cm}$ ) Salmo salar was not significantly different (chi-square test: $\mathrm{p}=0.35, \mathrm{df}=1$ ). Furthermore, the mean infection intensity $( \pm S D)$ in female and male $S$. salar was $49.8( \pm 10.7)$ and 46.6 $( \pm 15.4)$ copepods per fish, respectively, and the difference was not statistically significant ( $t$-test: $\mathrm{p}=$ $0.76, \mathrm{df}=79$, variance $\left[\mathrm{s}^{2}\right]=0.127$ ). Therefore, female and male fish of each life stage were pooled in the subsequent analysis.

Since most Salmo salar were released to the river after an in vivo examination, it was important to establish how accurate the in vivo infection scores were. For this task, the in vivo scores from the fish that were sampled were compared with the corresponding parasite counts from the laboratory. Since the in vivo data consisted only of score groups, the average number of parasites defining each group was used as in vivo data for the fish in each score group. By plotting the laboratory counts against the in vivo data for each fish, a fitted power trend line with the formula $y=0.7971$

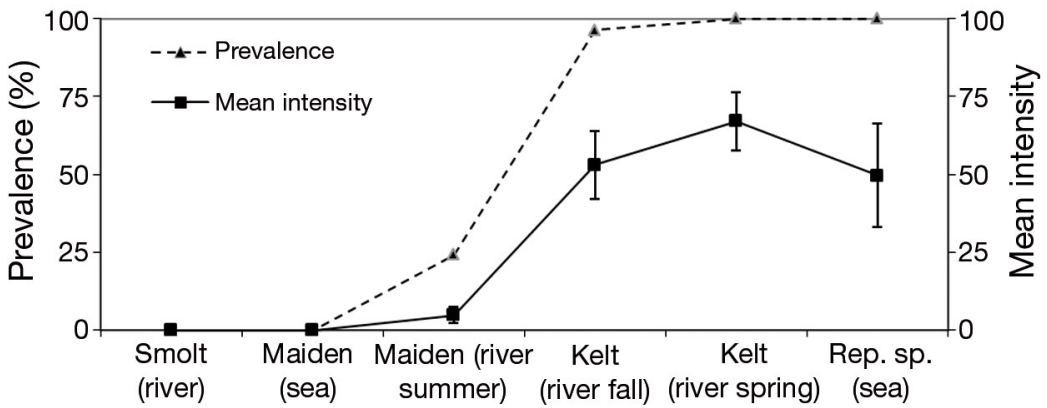

Fig. 2. Salmincola salmoneus. Prevalence and average infection intensity during different host life stages (mean intensity $\pm 95 \%$ CI). Rep. sp.: repeat spawners 

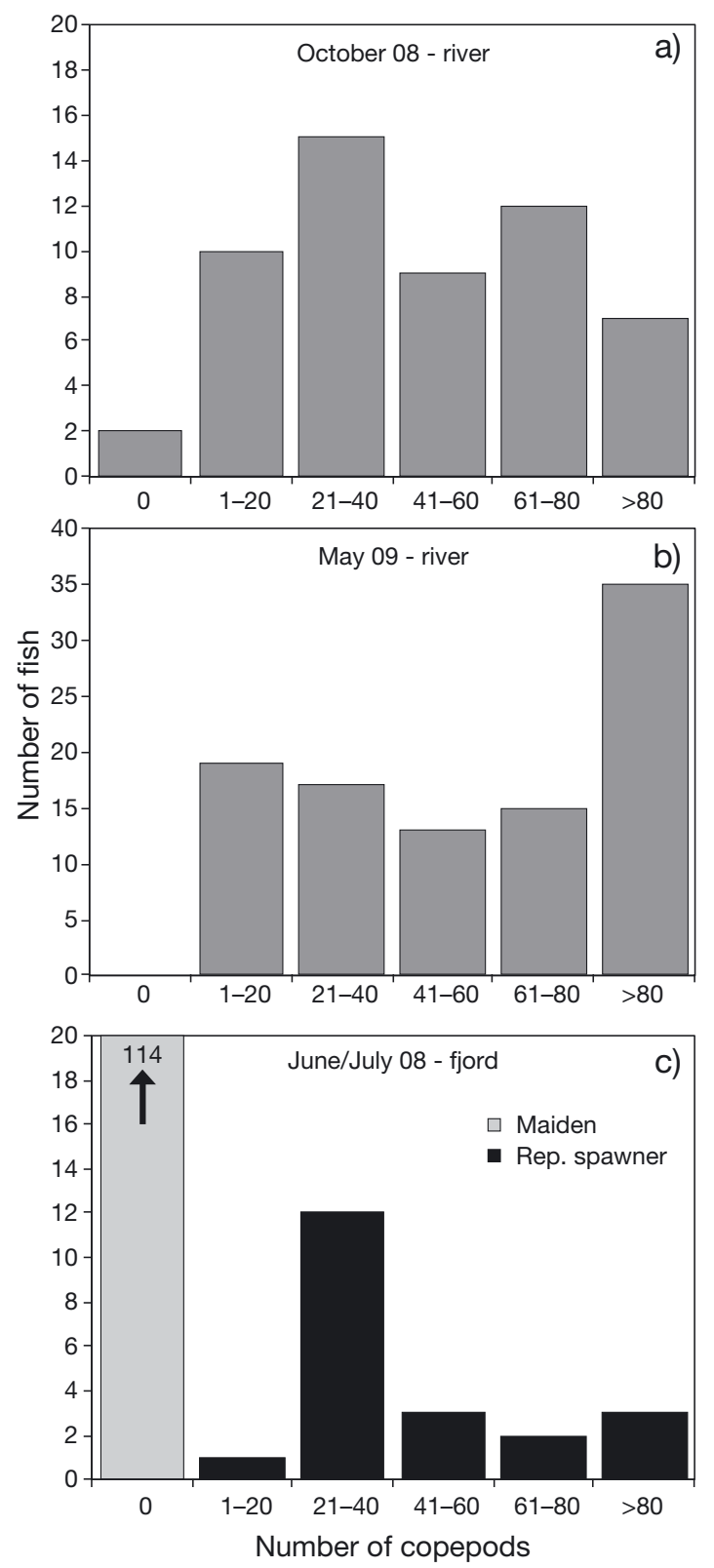

Fig. 3. Salmincola salmoneus. Frequency distribution of infection on different life stages of Salmo salar during a year: (a) kelts caught in fall 2008 in the river $(\mathrm{n}=55)$; (b) kelts caught in spring 2009 in the river $(\mathrm{n}=99)$; (c) fish caught in summer 2008 in the fjord divided into 2 groups: maiden fish or repeat spawners $(n=133)$

were simultaneously infected with $S$. salmoneus. The mean intensity of infection in this group was 4.7, while the mean abundance was 1.1.

There was a rapid increase in both prevalence and mean intensity in fall (October) 2008 when $96.4 \%$ of the fish that had spawned were infected with copepods at a mean intensity of 53 (Figs. 2 \& 3a), while the mean abundance was 51 (Table 2). The estimated
Table 2. Salmincola salmoneus. Infection parameters for different life stages of Salmo salar. All data except those for spring kelts and immature fall-run salmon are from fish caught in 2008 and analyzed in the laboratory. Data from spring kelts (2009) and immature fall-run fish are based on infection scores from released fish. Prev.: prevalence; Int.: intensity

\begin{tabular}{|lccccc|}
\hline Life stage & $\begin{array}{c}\mathrm{n} \text { Prev. } \\
(\%)\end{array}$ & $\begin{array}{c}\text { Mean } \\
\text { int. }\end{array}$ & \multicolumn{2}{c|}{$\begin{array}{c}\text { Mean } \\
\text { abundance }\end{array}$} & $\mathrm{s}^{2} / \bar{x}$ \\
\hline $\begin{array}{l}\text { Summer maiden } \\
\text { returners (river) }\end{array}$ & 29 & 24.1 & 4.7 & 1.1 & 2.3 \\
Fall kelts (river) & 55 & 96.4 & 53 & 51 & 0.8 \\
Spring kelts (river) & 99 & 100 & 67 & 67 & 0.7 \\
Fall immature (river) & 12 & 25 & 17 & 4.3 & 1.7 \\
Spring immature (river) & 20 & 100 & 20.2 & 20.2 & 0.7 \\
Repeat spawners (sea) & 19 & 100 & 49.6 & 49.6 & 0.7 \\
\hline
\end{tabular}

infection parameters for kelts in the fall of 2008 are based both on exact counts from 23 Salmo salar and rectified infection scores from 32 tagged and released fish (see above).

The following spring (May 2009), all examined kelts were infected with Salmincola salmoneus (Fig. 3b). The mean intensity of infection based on calculations from the scores was 67 (Table 2). Compared with fish caught in the fall of 2008, the frequency of Salmo salar with intensities higher than 80 S. salmoneus per individual had increased (Fig. 3). The data from kelts in 2009 consisted only of rectified field scores, and this approach was chosen to be able to follow the development of the infection from fall 2008 to spring 2009 since laboratory counts for spring-caught fish were only available from 2007 and 2008.

\section{Development of Salmincola salmoneus life stages throughout the Salmo salar life history}

A large majority (86\%) of Salmincola salmoneus that infected the maiden Salmo salar after they had entered the river in summer were immature, while approximately $10 \%$ were either mature or mature with eggs and the rest were unattached chalimus larvae (Fig. 4). In kelts and recently ascended immature fishes examined in the fall, the proportion of mature $S$. salmoneus individuals with eggs had increased significantly to $45 \%$, whereas about 20 and $35 \%$ were mature without eggs and immature, respectively (Fig. 4). In overwintered immature fall-run fish and descending kelts examined in the spring, the ratio of immature $S$. salmoneus was only $20 \%$, and the rest were mature or mature with eggs (Fig. 4). 


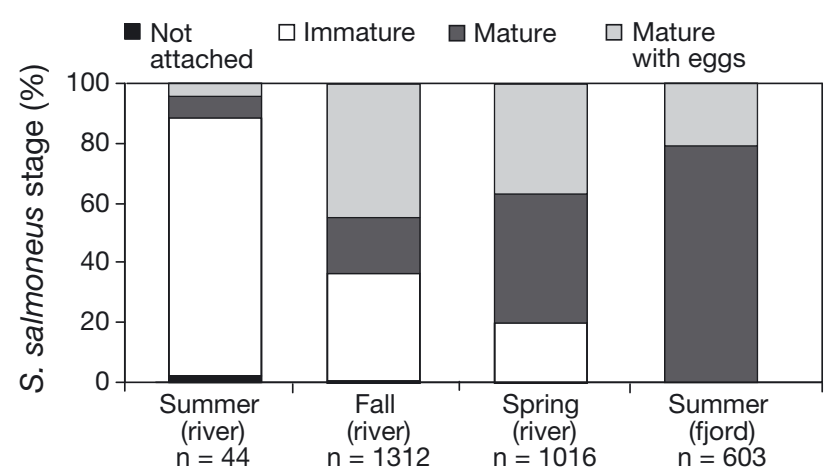

Fig. 4. Salmincola salmoneus. Relative proportion of different copepod life stages found on Salmo salar in summer (July-August), fall (October), spring (May) and summer (June-July in the fjord) 2008. The S. salmoneus life stages were taken from maiden fish in the river in summer, immature fall-run $S$. salar and kelts in fall and spring and repeat spawners in the fjord. Copepod life stage was only determined on gill samples examined in the laboratory (total number of fish $=62$ ). The number $(\mathrm{n})$ of copepods in each group is given below the $x$-axis

Returning repeat spawners that were caught in the fjord harbored only mature copepods, and approximately $20 \%$ of these copepods had extruded egg sacs containing eggs (Fig. 4). The earliest capture of a maiden $S$. salar infected by $S$. salmoneus carrying eggs in the river was made on 15 August 2008.

\section{Salmincola salmoneus infection of immature fall run Salmo salar}

Most of the fall-run immature Salmo salar were released to the river after they had been tagged (Table 1). Therefore their Salmincola salmoneus infection intensities were mainly estimated from scores. In fall (October), only $25 \%$ of the fish were infected with a mean intensity of 17 parasites per fish, whereas all were infected in spring. However,

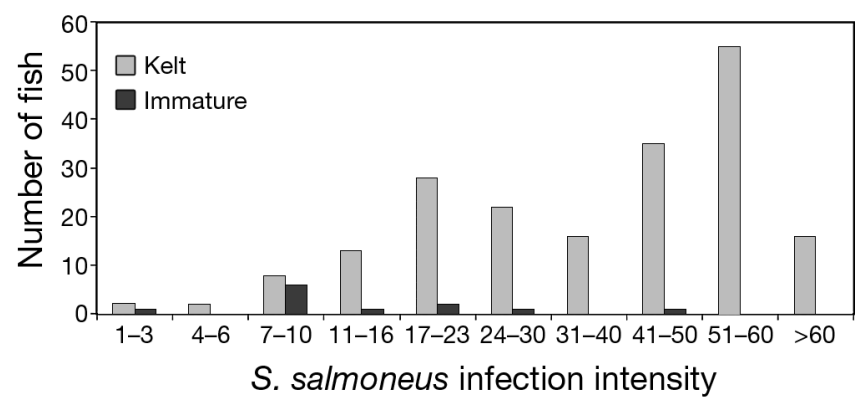

Fig. 5. Salmincola salmoneus. Frequency distribution of intensity scores of $S$. salmoneus numbers on kelts $(\mathrm{n}=197)$ and immature fall-run Salmo salar $(n=12)$ caught in spring 2008 in the river the mean intensity had not changed significantly ( $t$-test: $\mathrm{p}=0.92, \mathrm{df}=21, \mathrm{~s}^{2}=0.13$ ). Compared with the kelts in the spring, the immature fall-run $S$. salar that had spent the winter in the river had a significantly lower infection intensity ( $t$-test: $\mathrm{p}<0.01, \mathrm{df}=207, \mathrm{~s}^{2}=$ 4.51) (Table 2, Fig. 5).

\section{Salmo salar condition and Salmincola salmoneus infection}

The relationship between infection intensity and condition factor was examined by linear regressions in kelts caught in the fall and spring, respectively, and in repeat spawners caught in the fjord (Fig. 6), where only the latter group was found to exhibit a negative relationship between the 2 parameters $\left(r^{2}=0.4\right)$.

\section{DISCUSSION}

The present study is, to our knowledge, the first to investigate the life cycle of Salmincola salmoneus in Scandinavia. The utilization of the different Salmo salar life stages is similar to an earlier description from Scotland (Friend 1941). Three S. salar life stages in the river-kelts, repeat spawners and overwintered immature fall-run $S$. salar-were found to be infected with adult female $S$. salmoneus when maiden returning $S$. salar entered the river. These life stages therefore represented the main source of parasite transmission to the next generation. Although the present study was conducted on only one $S$. salar population, there is reason to believe that a comparable infection pattern can be found in other European and Russian rivers with similar S. salar life histories, as the parasite has been observed with high prevalence and intensity on $S$. salar from several other Norwegian populations (E. B. Thorstad pers. comm., A. H. Rikardsen pers. obs.).

\section{Infection rates of different Salmo salar life stages}

No Salmincola salmoneus were found on the smolts caught during their downstream migration. Therefore, infection of younger life stages of Salmo salar can be ruled out. This observation is supported by the findings for salmon populations in Scotland by Friend (1941), who suggested that the space between the gill branches of the smolt is too small for the infective larvae to pass through. However, reports 

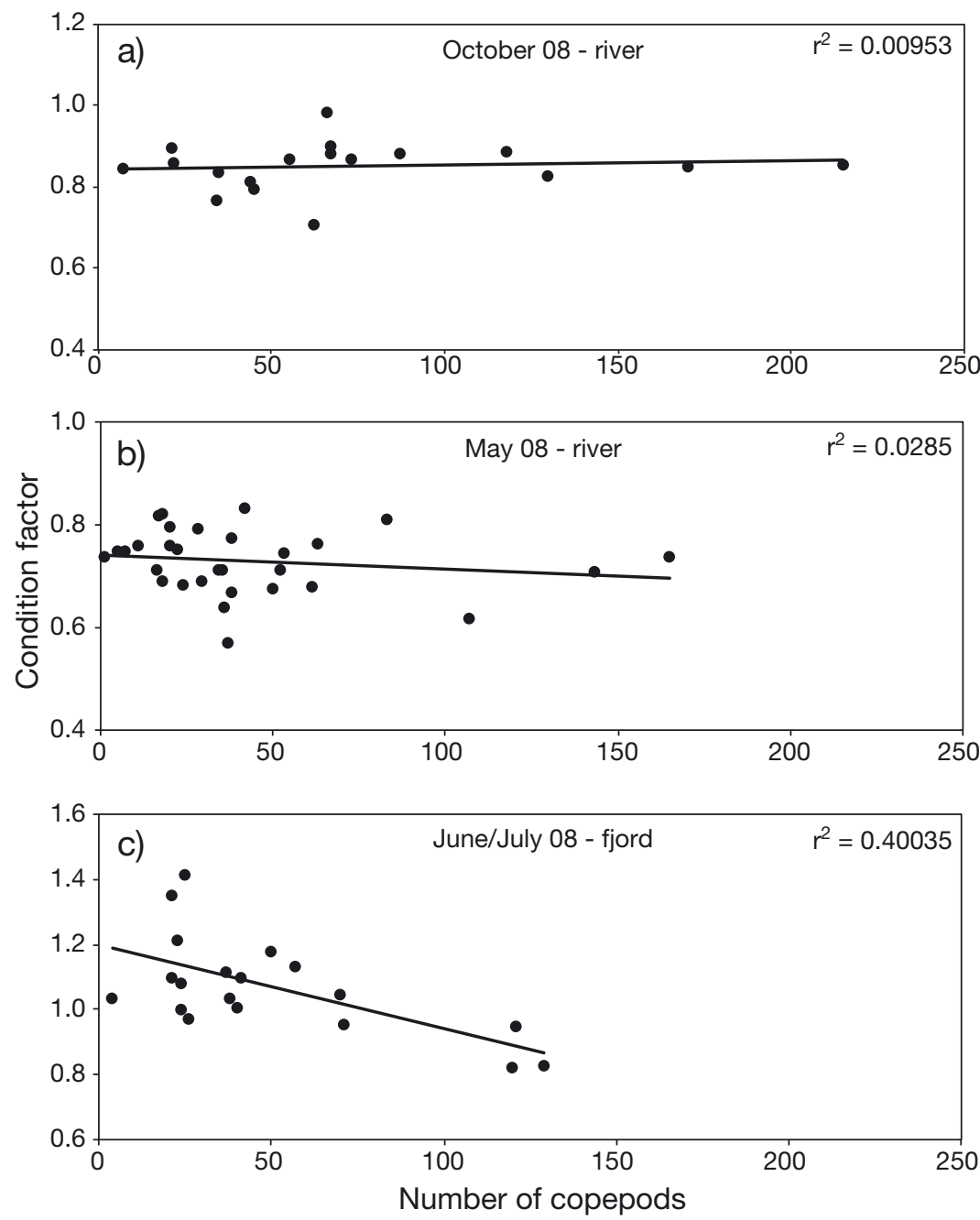

Fig. 6. Salmo salar. Condition factor $(K)$ of infected salmon examined in the laboratory correlated to their Salmincola salmoneus infection numbers for (a) kelts caught in the river in fall, (b) kelts caught in the river in spring and (c) repeat spawners caught in the fjord during summer. Note different scales on $y$-axis

from Canada indicate that up to $7.7 \%$ of the $S$. salar smolts there may be infected with $S$. salmoneus (Pippy 1969). Unfortunately, the size of these smolts was not reported. However, when comparing the length data of smolt caught in the present study and other Norwegian rivers (Rikardsen et al. 2004, Davidsen et al. 2009) with smolts from a Canadian $S$. salar population (Lacroix et al. 2004), the average smolt in Canada seems to be 5 to $6 \mathrm{~cm}$ longer. Thus, this size difference may be the reason for absence of $S$. salmoneus on European smolts (Friend 1941, Sandeman \& Pippy 1967). Still, this does not rule out other possible explanations such as immunity against $S$. salmoneus amongst European smolts and/or a different $S$. salmoneus life cycle in North America (Sandeman \& Pippy 1967). Further research will be required to determine if unequal fish size is the only reason for the difference in infection rates between $S$. salar smolts from North America and Europe.

None of the returning maiden Salmo salar caught at sea had Salmincola salmoneus present, which is consistent with the fact that none of the smolts leaving the river were infected. If the smolts had been infected before they entered the sea for the first time, some copepods would most likely have survived the sea migration. However, based on the lack of $S$. salmoneus on smolts, we assume that the returning maiden S. salar had never been infected.

During summer (June to August), the maiden Salmo salar entered the river to spawn for the first time. None of the recently arrived maiden $S$. salar still carrying the marine parasite Lepeophtheirus salmonis had visible Salmincola salmoneus infections. In contrast, S. salar without L. salmonis had $S$. salmoneus present, but the abundance was very low. This suggests that it takes some weeks from the time maiden fish enter the river until the first $S$. salmoneus are big enough to become permanently attached, and hence are visible on the gills. In the river, the earliest observation of $S$. salmoneus with egg sacs (2 individuals) was made in mid-August on a female $S$. salar with spawning coloration. Compared with the population structure of $S$. salar in this river it was a small individual $(5.9 \mathrm{~kg})$ and, based both on the small size and low infection intensity ( 9 parasites), most likely a maiden fish. Therefore the first parasite establishment must have taken place when the fish entered the river, at the earliest in the beginning of June. This indicates that the development time from copepodid to egg-laying female during the summer is less than $2.5 \mathrm{mo}$ in the Alta River, which is half of the time that was suggested from a Scottish river (Friend 1941).

The infection intensity on maiden Salmo salar in summer was much lower than on kelts in late fall, and the prevalence of Salmincola salmoneus increased from $27 \%$ in the summer to $96 \%$ in late fall on $S$. salar that had entered the river earlier the same year. This suggests that parasite reproduction, and 
hence the rate of new infections within the $S$. salar population, is most intense during this period. In winter, the prevalence increased even further to $100 \%$, but the mean intensity did not change significantly. Water temperatures close to $0^{\circ} \mathrm{C}$ in winter prevent $S$. salmoneus growth and egg development (McGladdery \& Johnston 1988), and thereby also the release of infective larvae. S. salmoneus can only produce egg sacs a few times before they die of exhaustion (Friend 1941), a trait also known from other copepodid species (Ritchie et al. 1993). In addition, infection tests with $S$. salmoneus on spring kelts have previously indicated that they are not susceptible to new infections (Friend 1941), but the reason for this remains unclear. Thus, the combined effect of low water temperature, S. salmoneus exhaustion and mortality and host insusceptibility is the most likely reason for the insignificant change in the mean intensity of $S$. salmoneus during winter. In addition, the most heavily infected $S$. salar in the fall may experience a lower post-spawning survival rate than the less-infected individuals, which would also influence the infection intensity in spring. Unfortunately, this could not be examined in the present study since we were not able to follow individual fish through the winter in the river.

The high percentage of egg-carrying Salmincola salmoneus in spring is caused by simultaneous initiation of egg production with rising water temperatures. During fall, winter and spring, infected immature fall-run Salmo salar were also present in the river. They enter the river in fall and are resident in the river until the next fall when they spawn with the fish of the summer run, probably representing $<4 \%$ of the overwintering adult individuals in the river (A. H. Rikardsen et al. unpubl. data). The low prevalence $(20 \%)$ and intensity of S. salmoneus on these fish in the autumn are a result of the late river entry during fall. Although the infection prevalence had increased to $100 \%$ in spring for the immature fall-run $S$. salar, the mean intensity of infection remained almost unchanged. While some heavily infected kelts could be expected to die after spawning, thereby masking any increase in the estimate of intensity in these fish during winter (see earlier), it is unlikely that the immature fish suffer from any mortality as a result of $S$. salmoneus infection. The low parasite intensities on immature fall-run fish in the spring further confirms the assumption that there is no reproduction of copepods during winter. However, even if these immature fish carry significantly lower numbers of $S$. salmoneus than the kelts in the spring, they still represent a habitat for the parasite. It is unknown if the suggested immunity against new infection that Friend (1941) reported from kelts after a winter in the river is also occurring in immature fall-run $S$. salar. If so, it should be expected that these fish, despite their long residency in the river, exhibit lower S. salmoneus intensities during spawning than the 'normal' $S$. salar that enter the river the same year as they spawn. To test this further, immature fall-running fish should be analyzed for parasites and tagged in the spring to be recaptured and examined again later in summer or fall.

\section{Parasite-host interaction model}

The earliest maiden Salmo salar that enter the river during June and early July will usually arrive before the out-migration of the kelts has ended (Halttunen et al. 2009). All kelts carried Salmincola salmoneus in spring, and the percentage of egg-carrying copepods was also high in May. Therefore, the $S$. salmoneus larvae hatching from these adult parasites present on the kelts in the river in May represent a source for high infection pressure upon the maiden $S$. salar that enter the river during early summer. This can be seen as the first of 2 main transmission peaks during a year cycle (Fig. 7).

Maiden Salmo salar that did not become infected by Salmincola salmoneus larvae from the kelts in early summer, or entered the river after the spring kelts had left, must have become infected by larvae with an alternative origin. In the same period as maiden S. salar entered the river, repeat spawners, which all were infected with $S$. salmoneus, also ascended the river. These fish probably make up 5 to $10 \%$ of all S. salar entering the river (Halttunen 2011). The $S$. salmoneus carried by the repeat spawners were all mature females and start producing eggs as soon as they enter fresh water, and these eggs are likely to hatch approximately $2 \mathrm{wk}$ later (Friend 1941). On one of the repeat spawners caught in the fjord for this study, most of the copepods had already developed egg sacs, probably because the host fish had already been in fresh water, either in the Alta River or another river, and returned to sea (Jensen et al. 2010, Thorstad et al. 2011) before it was caught in a bag net just a few kilometers from the river mouth. The increasing numbers of mature $S$. salmoneus carried by repeat spawners as more of them entered the river throughout the summer represented a steadily increasing source of infective parasite larvae (Fig. 7). At the same time, the immature fall-run $S$. salar that 

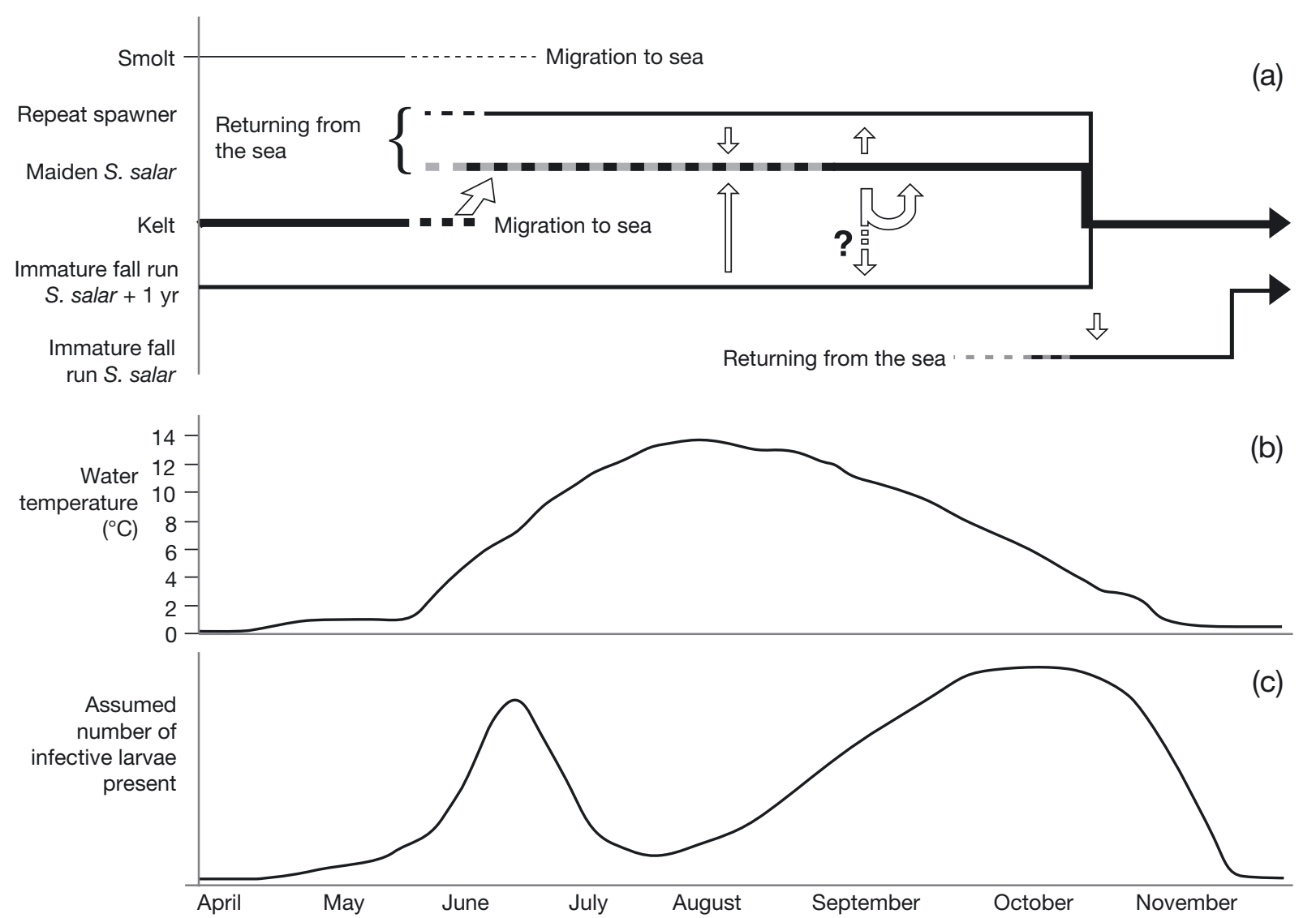

Fig. 7. (a) Model of the host-parasite interactions between Salmo salar and Salmincola salmoneus in the Alta River. Grey lines indicate $S$. salar without $S$. salmoneus infection and black lines represent $S$. salar with infection. Open arrows indicate the direction of infection (note that immature $S$. salar entering the river during fall are infected by $S$. salmoneus from all adult spawning $S$. salar present in the river in this period). Thick lines indicate the main host source for $S$. salmoneus and the main route of transmission. In October, immature fall-run $S$. salar that have been in the river for 1 yr, maiden $S$. salar and repeat spawners spawn together and become kelts. New infection of immature $S$. salar after a winter in the river could not be documented and is, therefore, marked with a question mark and a dashed arrow. (b) River water temperature and (c) assumed relative amount of infective $S$. salmoneus larvae within the river, based on the results of the present study

entered the river the year before also carried eggproducing $S$. salmoneus. Since their individual numbers are assumed to be relatively low in the river, and their $S$. salmoneus infection was significantly lower than that of the kelts, they do not represent a significant infection source during early summer. However, in July and August they, together with the repeat spawners, represent a substantial source of infection. Especially in the case of an early out-migration of kelts and a late river entry of maiden $S$. salar, the repeat spawners and immature fall-run $S$. salar play an important role in maintaining the parasite population.

From August, when the Salmincola salmoneus attached to Salmo salar that ascended early in summer started to produce eggs, the density of infective larvae in the river is assumed to have increased until decreasing water temperatures halt the egg develop- ment in late fall. This period is seen as the second period of high transmission during one growing season where maiden $S$. salar will transmit the parasites to each other (Fig. 7). Findings of a single chalimus larva on fish caught in August and 8 chalimus larvae on fish caught in October support this assumption.

\section{Effect of the parasite on Salmo salar}

Eventual effects of Salmincola salmoneus infection upon the host's health are most likely to be found in the repeat spawners since they have been infected for the longest period of time (i.e. during one or more stays within the river habitat and after marine migration). In this study, the condition factor $(K)$ was used as an indicator of Salmo salar feeding and growth performance during the seaward migration, and this 
parameter showed a negative relationship to the infection intensity in the repeat spawners, but not in the kelts. According to McGladdery \& Johnston (1988), S. salmoneus infection is possibly lethal. The assumption that $S$. salmoneus have a negative influence on their hosts was also supported by Friend (1941), who suggested that $S$. salmoneus, when present in great numbers, feed on the blood and tissue of the gills, which may reduce host oxygen intake, demand a higher effort from the host to maintain osmotic balance, cause anemia and also increase the risk of secondary infections. It has also been suggested that Salmincola edwardsii, another species of parasitic copepod that infects members of the genus Salvelinus, can kill its host when it occurs in large numbers (Fasten 1912). The present data from repeat spawners suggest that $S$. salar may be negatively affected by the parasite on long-term basis by reducing the fish's growth potential and lowering its energy reserves, although the number of fish examined was relatively small. We suggest conducting tag-and-recapture studies of infected fish to investigate whether high infection intensity reduces marine growth and survival, and subsequently reproductive success of multi-spawning fish.

\section{CONCLUSIONS}

Based on the present results, juvenile Salmo salar from Alta River are not used as hosts for Salmincola salmoneus, either in fresh water or in the sea. Kelts in the river seem to be the main habitat for the parasite during the winter and spring, which is similar to findings from a $S$. salar population in Scotland (Friend 1941). The kelts generally stay in fresh water long enough to pass on the parasite to the maiden $S$. salar that enter the river in early summer. The laterrunning maiden $S$. salar can be infected by the early running maiden $S$. salar that originally received the infection from the kelts. This is believed to be the major route of infection. However, in case of mismatched timing between kelt sea entry and maiden $S$. salar river entry, the $S$. salmoneus can also be transmitted in 2 alternative ways: (1) through infected immature fall-run $S$. salar that are believed to remain in the river for $1 \mathrm{yr}$ until they spawn and (2) by returning repeat spawners that carry parasites ready to produce eggs as soon as the fish enter fresh water. Both alternatives should, on their own, be able to facilitate the further existence of $S$. salmoneus on the $S$. salar population of the river, but probably with much lower prevalence and intensity.
Acknowledgements. We thank E. Halttunen and J. L. A. Jensen for help during the fieldwork. We are also thankful to T. F. Næsje at NINA for contributing with scale analysis, R. Primicerio for advice on statistical questions, Alta Laksefiskeri Interessentskap (the local river management association) for support during the fieldwork and the commercial fishers in the Alta fjord and anglers in the river for catching sample fish. The study was supported by the Norwegian Research Council (project no. 17601/S40) and the University of Tromsø.

\section{LITERATURE CITED}

Berland B (1993) Salmon lice on wild salmon in Norway. In: Boxshall GA, Defaye D (eds) Pathogens of wild and farmed fish: sea lice. Ellis Horwood, Chichester, p 179-187

Bristow GA (1993) Parasites of Norwegian freshwater salmonids and interactions with farmed salmon-a review. Fish Res 17:219-227

$>$ Bristow GA, Berland B (1991) A report on some metazoan parasites of wild marine salmon (Salmo salar L.) from the west coast of Norway with comments on their interactions with farmed salmon. Aquaculture 98:311-318

Bristow GA, Alvik TA, Bohne H (1996) Some parasites of marine salmonids from Tanafjorden, Finnmark, Norway. Bull Scand Soc Parasitol 6:25-32

Bush AO, Lafferty KD, Lotz JM, Shostak AW (1997) Parasitology meets ecology on its own terms: Margolis et al. revisited. J Parasitol 83:575-583

Dahl K (1910) Alder og vekst hos laks og ørret belyst ved studiet av deres skjæl. Centraltrykkeriet, Kristiania

> Davidsen JG, Rikardsen AH, Halttunen E, Thorstad EB and others (2009) Migratory behavior and survival rates of wild northern Atlantic salmon Salmo salar post-smolts: effects of environmental factors. J Fish Biol 75:1700-1718

Fasten N (1912) The brook trout disease at Wild Rose and other hatcheries (The brook trout disease in Wisconsin waters). Rep Wis Fish Comm 1911-1912, p 12-22

Finstad B, Bjørn PA, Nilsen ST (1995) Survival of salmon lice, Lepeophtheirus salmonis Krøyer, on Arctic charr, Salvelinus alpinus L., in fresh water. Aquac Res 26: 791-795

Finstad B, Bjørn PA, Todd CD, Whoriskey F, Gargan PG, Forde G, Revie CW (2011) The effect of sea lice on Atlantic salmon and other salmonid species. In: Aas $\varnothing$, Einum S, Klemetsen A, Skurdal J (eds) Atlantic salmon ecology. Wiley-Blackwell, Chichester, p 253-276

Friend GF (1941) The life-history and ecology of the salmon gill-maggot Salmincola salmonea (L.) (Copepod Crustacean). Trans R Soc Edinb 60:503-541

Hahnenkamp L, Fyhn HJ (1985) The osmotic response of salmon louse, Lepeophtheirus salmonis (Copepoda: Caligidae), during the transition from sea water to fresh water. J Comp Physiol 155:357-365

Halttunen E (2011) Staying alive: the survival and importance of Atlantic salmon post-spawners. PhD thesis, University of Tromsø. http://hdl.handle.net/10037/3536

Halttunen E, Rikardsen AH, Davidsen JG, Thorstad EB, Dempson JB (2009) Survival, migration speed and swimming depth of Atlantic salmon kelts during sea entry and fjord migration. In: Nielsen JL, Arrizabalaga H, Fragoso N, Hobday A, Lutcavage M, Sibert J (eds) Tagging and tracking of marine animals with electronic devices II. 
Reviews: methods and technologies in fish biology and fisheries, Vol 9. Springer, Dordrecht, p 35-49

Harris PD, Bachmann L, Bakke TA (2011) The parasites and pathogens of the Atlantic salmon: lessons from Gyrodactylus salaris. In: Aas $\varnothing$, Einum S, Klemetsen A, Skurdal J (eds) Atlantic salmon ecology. Wiley-Blackwell, Chichester, p 221-252

Heuch PA, Bjørn PA, Finstad B, Holst JC, Asplin L, Nilsen F (2005) A review of the Norwegian 'National Action Plan Against Salmon Lice on Salmonids': the effect on wild salmonids. Aquaculture 246:79-92

Jensen JLA, Rikardsen A, Næsje TF, Thorstad EB, Halttunen E, Suhr AH, Leinan I (2010) Fangstrater, oppvandring og fordeling av laks i Altaelva. NINA Rapp 595. NINA, Trondheim

Johnsen BO, Jensen AJ (1991) The Gyrodactylus story in Norway. Aquaculture 98:289-302

Kabata Z (1969) Revision of the genus Salmincola Wilson, 1915 (Copepoda: Lernaeopodidae). J Fish Res Board Can 26:2987-3041

Kabata Z (1981) Copepoda (Crustacea) parasitic on fishes: problems and perspectives. Adv Parasitol 19:1-71

Kabata Z, Cousens B (1973) Life cycle of Salmincola californiensis (Dana 1852) (Copepoda: Lernaeopodidae). J Fish Res Board Can 30:881-903

Lacroix GL, McCurdy P, Knox D (2004) Migration of Atlantic salmon postsmolts in relation to habitat use in a coastal system. Trans Am Fish Soc 133:1455-1471

Lund RA, Hansen LP, Järvi T (1989) Identifisering av oppdrettslaks og vill-laks ved ytre morfologi, finnestørrelse og skjellkarakterer. NINA Forskningsrapp 001. NINA, Trondheim

McGladdery SE, Johnston CE (1988) Egg development and control of the gill parasite, Salmincola salmoneus, on Atlantic salmon kelts (Salmo salar) exposed to four different regimes of temperature and photoperiod. Aquaculture 68:193-202

Næsje TF (1998) Altalaksen. Kultur, kraftutbygging og livsmiljø. Alta Kommune, Alta

Editorial responsibility: David Marcogliese, Montreal, Quebec, Canada
Pippy JHC (1969) Preliminary report on parasites as biological tags in Atlantic salmon (Salmo salar). Fish Res Board Can Tech Rep 134. Fisheries \& Oceans Canada, Ottawa

Rikardsen AH, Haugland M, Bjørn PA, Finstad B and others (2004) Geographical differences in marine feeding of Atlantic salmon post-smolts in Norwegian fjords. J Fish Biol 64:1655-1679

Ritchie G, Mordue AJ, Pike AW, Rae GH (1993) The reproductive output of Lepeophtheirus salmonis adult females in relation to seasonal variability of temperature and photoperiod. In: Boxshall GA, Defaye D (eds) Pathogens of wild and farmed fish: sea lice. Ellis Horwood, Chichester, p 153-165

Sandeman IM, Pippy JHC (1967) Parasites of freshwater fishes (Salmonidae and Coregonidae) of insular Newfoundland. J Fish Res Board Can 24:1911-1943

Smith H (1983) Noen parasitter på laksefisk i Norge. En undersøkelse basert i hovedsak på materiale innsamlet av amanuensis Hans Nordeng, Universitetet i Oslo. Cand Sci [= MSc] thesis, University of Bergen

Thorstad EB, Whoriskey F, Rikardsen AH, Aaresrup K (2011) Aquatic nomads: the life and migrations of the Atlantic salmon. In: Aas $\varnothing$, Einum S, Klemetsen A, Skurdal J (eds) Atlantic salmon ecology. Wiley-Blackwell, Chichester, p 1-32

Ugedal $\mathrm{O}$, Thorstad EB, Finstad AG, Fiske $\mathrm{P}$ and others (2007) Biologiske undersøkelser i Altaelva 1981-2006. Oppsummering av kraftreguleringens konsekvenser for laksebestanden. NINA Rapp 281. NINA, Trondheim

Ugedal O, Næsje TF, Thorstad EB, Forseth T, Saksgård LM, Heggberget TG (2008) Twenty years of hydropower regulation in the River Alta: long-term changes in abundance of juvenile and adult Atlantic salmon. Hydrobiologia 609:9-23

Ugedal O, Thorstad EB, Saksgård L, Næsje TF (2009) Fiskebiologiske undersøkelser i Altaelva 2008. NINA Rapp 478. NINA, Trondheim

Weatherley AH (1972) Growth and ecology of fish populations. Academic Press, London

Submitted: February 24, 2011; Accepted: May 22, 2012

Proofs received from author(s): August 1, 2012 